\title{
THE HOT “COLD WAR”: THE USSR IN SOUTHERN AFRICA
}

\section{Vladimir Shubin}

London: Pluto Press, 2008 \& Scottsville: University of KwaZulu-Natal Press, 2008 $320+$ xvi pages

Index, list of abbreviations, list of Soviet Personalities, 10 photographs and a map. ISBN 9780745324739 (Hardback)

ISBN 9780745324722 (Pluto Press paperback)

ISBN 9781869141554 (University of KwaZulu-Natal Press paperback)

R190,00 (University of KwaZulu-Natal Press paperback)

Vladimir Shubin is the Deputy Director of the Institute for African Studies in the Russian Academy of Sciences and a former officer in the Soviet armed forces, and subsequently, a member (eventually secretary) of the Soviet Afro-Asian Solidarity Committee and desk officer (eventually head) of the African Section of the Communist Party of the USSR. In the latter two capacities he became intensely involved in supporting Southern African liberation movements on behalf of the USSR.

In The Hot "Cold War": The USSR in Southern Africa Shubin aims to "set the record straight' with regard to Moscow's involvement in Southern Africa during the Cold War, especially the role of the Soviet military, which he believes 'is covered inadequately or even distorted' (p. xv). His work is divided into five parts dealing in succession with the liberation struggles in Angola, Mozambique, Zimbabwe, Namibia and South Africa during the period 1960 to 1990. These parts are preceded by a short introduction and followed by a brief postscript. Shubin devotes the bulk of his discussion (109 pages) to Angola, followed by Zimbabwe and Namibia (41 
pages each). Mozambique (29 pages) and South Africa ${ }^{1}$ (25 pages) get significantly less attention.

The author explored a fair amount of primary sources, including documents from Russian formal and informal archives and the archives of the ANC and the SACP for his work, but acknowledges that he did not have access to 'most of the relevant materials' (p. xv) as they are still classified. In an effort to bridge this extremely wide gap Shubin relied heavily on the memoirs and oral evidence of participants of the events. He also made extensive use of notes that he accumulated during the era of the liberation struggles, as well of as his own memory. Although he tries to deal 'not uncritically' (p. 7) with these inherently biased sources, his work is unavoidably subjective, as he admits in his preface (p. xvi), and has a strong autobiographical 'flavour'. Shubin supports his narrative with a list of notes and references for the various chapters at the end of the book, but unfortunately does not include a select bibliography to give the reader a bird's eye view of the scope and comprehensiveness his sources.

As Shubin stresses (p. 3), his book does not offer a comprehensive, systematic analysis of the role of the USSR in Southern Africa during the Cold War era. It provides a rather broad coverage of the topic, often concentrating on 'setting the record straight' on popular western misperceptions and the mistakes of other authors and commentators. A particular weakness of the book is that Shubin chose not to 'consider the theoretical issues of international relations at the time' (pp. 3-4). An introductory chapter on Soviet Cold War foreign policy to put the USSRs involvement in Southern Africa in perspective would indeed have added much value to his work.

In his endeavour to 'set the record straight', Shubin discards what he calls the 'tendency... of Western academics and politicians, to look at the armed conflicts in Southern Africa... primarily through the distorting prism of superpowers' rivalry during the "Cold War" .' (p. 2). He concedes that Soviet-USA relations influenced Moscow's decision-making on Southern Africa, but contends that the USSR did not support liberation movements only because of the Cold War; the Soviet Union also regarded these struggles as part of the "world "anti-imperialist struggle", which was waged by the "socialist community", the "national liberation movements", and the "working class of the capitalist countries".' (p. 3). He argues furthermore that the term 'Cold War' was not even part of the Soviet 'political vocabulary' and that they in fact used the term in a 'strictly negative sense'. The Soviets considered it to be

1. Shubin only touches upon the most important aspects of the liberation struggle in South Africa in this book, since he has dealt with it in detail in another book: $A N C$ : A View from Moscow (Bellville: Mayibuye Books, 1999). 
'the creation of "war mongers" and imperialist propaganda'. For them 'the global struggle was not a battle between the two "superpowers" assisted by their "satellites" and "proxies", but a united fight of the world's progressive forces against imperialism' (p. 3). Hence he strongly rejects the notion of Soviet intervention in liberation struggles as 'proxy wars' in the conflict between the two superpowers (pp. 111-112), as well as the popular western perception that 'Cubans acted in Angola as Soviet "proxies", (p. 52). He contends that 'archive documents and oral sources prove that Havana's decision (to send military forces to Angola) was its own' (p. 52) and points out that the two powers often differed about military strategy in Angola. At the same time he points out that the Cubans were almost completely dependent upon Soviet supplies and equipment and leaves no doubt in the reader's mind that the Soviet Union was the senior foreign partner in Angola.

Another Western misperception that Shubin tries to set straight is the notion that "the Soviet Union was just a "monolithic" structure where a top-down approach prevailed' (p. 49). He stresses that 'different opinions were expressed on various critical issues' (p. 186). He furthermore quotes Georgy Kornienko ${ }^{2}$ in this regard who referred to 'the "sad consequences of the two approaches in Soviet foreign policy - state and ideological - and the related institutional confusion"' (p. 50).

Against the above background Shubin contends that the 'Moscow-Washington confrontation' was by far not the only reason for the USSR's support of liberation movements in Southern Africa. An 'obvious reason' in his view, 'so typical of the Russian mentality', was 'human sympathy for the "weaker side"... fighting for a just cause' (pp.1, 2). Hence the Soviet Union did not, in the words of Rostislav Ulyanovsky, ${ }^{3}$ " "request ideological loyalty from the liberation movements" , (p. 16), although it did welcome, for example, the Popular Movement for the Liberation of Angola's (MPLA) 'move towards Marxism' (p. 16). When they had to choose between liberation movements within a state, they supported the movement which appeared to be the most viable and also the most legitimate representative of the people. In Angola the USSR supported the MPLA rather than the Union for Total Liberation of Angola (UNITA) and the National Front for Liberation of Angola (FNLA) because the former, in their view, was the only legitimate representative of the Angolan people. Chino-Soviet rivalry of course also influenced the USSR's choice. The Front for the Liberation of Mozambique (FRELIMO) was the only liberation movement in Mozambique, but its relationship with China had a negative

2. First Deputy Minister of Foreign Affairs and later First Deputy Head of the International Department of the Communist Party of the Soviet Union.

3. Deputy Head of the International Department of the Communist Party of the Soviet Union and Vice-President of the Soviet Afro-Asian Solidarity Committee. 
impact upon its 'closeness' to the Soviet Union initially (pp. 124 - 127). However, Shubin stresses that when FRELIMO organised itself into a Marxist-Leninist party in 1977, 'the choice in favour of socialism was made by the Mozambicans themselves, and not imposed by Moscow' (p. 139). In Zimbabwe the Soviet Union supported the Zimbabwe African People's Union (ZAPU) from the early 1960s and continued to do so when the Zimbabwe African National Union (ZANU) split off in 1963, mostly because ZANU established 'close contacts with China' (p. 159). In the case of Namibia the USSR initially leaned towards the South West Africa National Union (SWANU) because it had a national character while the South West Africa People's Organisation (SWAPO) was ethnically (Ovambo) based. However, when SWANU leaders 'took an openly pro-Chinese" stand' (p. 197) in late 1963, Soviet support shifted to SWAPO. SWAPO representatives of course also visited Beijing regularly, but 'were not following every twist of the Chinese policy' (p. 197). Regarding the liberation struggle in South Africa, Shubin discusses the South African Communist Party (SACP) and the African National Congress (ANC) only and does not even mention the Pan African Congress (PAC). He offers no explanation for this obvious gap.

Shubin emphasises the wide spectrum of Soviet support of liberation movements in Southern Africa, ranging from financial assistance, medical aid, food and other civilian supplies, to academic education, military and political training in the USSR and in African countries, the supply of weapons and other war materials, and the provision of military advisors and specialists and political/diplomatic aid, all according to the call of circumstance. In all this the eyes of the Soviet Union were always on the threat from 'racist' South Africa. Shubin holds, for instance, that the activities of RENAMO were 'guided, or rather commanded by Pretoria'. Hence the heavy weapons that the USSR supplied to Mozambique and which could arguably not have been effectively employed against RENAMO, were primarily intended to deter South Africa. Shubin believes that Mozambique's mere possession of those weapons indeed 'served as a restraint to South Africa' (p. 141). He states furthermore that the USSR was undoubtedly 'worried by Pretoria's nuclear programme', but denies that South Africa 'successfully used the threat of nuclear explosion, in the process of getting the Cubans to leave Angola' (p. 143). He, however, believes that the nuclear threat might have served 'as leverage in relations between Maputo and Pretoria' (p. 143), because by 1983 the Mozambican leadership actually, according to FRELIMO leader Sergio Vieira, “ "dispersed the government and organised the survival of the state in case Maputo should be destroyed" ' ( $\mathrm{p}$. 144). The years 1986-187/88, which were the first years of Gorbachev's perestroika, were, in Shubin's view, 'the peak of Moscow's relations with the ANC' (p. 256). He argues that the intensification of the liberation struggle in South Africa 
and the 'growing recognition of the ANC as its leader created an atmosphere where negotiations on a political settlement, on the eradication of apartheid by peaceful means, were becoming feasible' and contends that 'multi-faceted support for the ANC from the USSR facilitated it' (p. 258).

In conclusion Shubin emphasises that most of the conflicts in the world during the Cold War resulted from the internal dynamics of particular regions rather than from the ideological struggle between East and West. In Southern Africa, he contends, the conflict was spawned by people's desire to get rid of colonialism and apartheid and the resistance of Pretoria, Salisbury and Lisbon and their Western sponsors to 'inevitable decolonisation' (p. 264). He concedes that Superpower involvement often made the conflicts harsher, but contends that on rare occasions they also 'helped to extinguish the fire' (p. 264). He asserts that Moscow's involvement with the liberation struggles, particularly in the training of freedom fighters, 'helped to prevent them from using terrorist methods' and that refusal to use such methods was 'as a rule, a striking feature of all the liberation movements supported by the Soviet Union' (p. 265). Moscow's greatest contribution to 'the elimination of colonialism and apartheid', however, was in his estimation 'not material assistance or the provision of training facilities, but the encouragement of non-racialism through fraternal relations, which developed between "white" Soviets and "black" members of the liberation movements' (p. 265).

Like his principal sources, Shubin's work is rather one-sided and carries the unmistakable stamp of his politico-ideological background, leaving fairly little room for a really critical, 'objective' look at the role of the Soviet Union in Southern Africa's Cold War history. It nevertheless casts some new light on the contemporary perceptions, aims and actions of the USSR and indeed makes a useful contribution to the literature in this field. It should not be ignored by anyone seriously attempting to understand the context, course and outcomes of the liberation struggles of Southern Africa in the second half of the twentieth century.

Lt Col (Prof) Deon Visser, Department of Military History, Faculty of Military Science, Stellenbosch University 